Rzetelność intelektualna sygnalizowanych zamierzeń oraz efektywność ich realizacji były wielokrotnie doceniane przez środowisko Kujaw. W 1996 r. Władze Miasta Inowocław nadały Profesor Aleksandrze Cofcie-Broniewskiej tytuł Honorowego Obywatela.

Żegnając w majowe, gorące popołudnie naszą Mistrzynię, byliśmy świadomi, jak wiele jesteśmy Jej winni za prawie półwiecze wielostronnych, matczynie ciepłych, inspiracji. Dotyczy to m.in. „depozytu millenialnej strategii”: stałej, odczuwalnej obecności naszej dyscypliny w życiu społecznym, jako podstawowego warunku aktywnego, efektywnego wykonywania zawodowych obowiązków, ochrony i rozpoznania naukowego narodowego dziedzictwa archeologicznego.

\author{
Józef Bednarczyk \\ Aleksander Kośko \\ Barbara Stolpiak
}

Instytut Prahistorii, Uniwersytet im. A. Mickiewicza

ul. Św. Marcin 78, 61-809 Poznań, Poland

\title{
OBJAZD NAUKOWY STUDENTÓW II ROKU ARCHEOLOGII W 2013 R.
}

Inicjatywa organizacji objazdów naukowych ma w historii uniwersyteckiego kształcenia długą tradycję, wywodzącą się jeszcze z oświeceniowych podróży kształceniowych, zwanych Grand Tour lub Bildungsreise. Owe ekspedycje zmieniały swój charakter z indywidualnych podróży zamożnych arystokratów, pragnących zapoznać się z reliktami starożytnych cywilizacji, aż po zorganizowane wyprawy dydaktyczne grupy studentów pod kierunkiem nauczyciela akademickiego. W XX w. na wielu uniwersytetach objazdy naukowe zostały ujęte w programach studiów archeologicznych.

O ile sam fakt odbywania tego typu uzupełniających zajęć akademickich stał się w Poznaniu normą, usankcjonowaną decyzją Rady Instytutu, o tyle organizacja zagranicznych objazdów naukowych nie była w historii Instytutu zjawiskiem częstym, a w przypadku podróży do krajów śródziemnomorskich - wręcz bardzo rzadkim. Zachodnie tereny basenu Morza Śródziemnego nie były celem objazdów naukowych do 1986 r., kiedy Koło Naukowe Studentów Archeologii zorganizowało objazd po Półwyspie Iberyjskim. W tym świetle należy wspomnieć o inicjatywie dr. hab. Andrzeja Michałowskiego, który był pomysłodawcą autokarowego wyjazdu szkoleniowego studentów II roku do Hiszpanii. Piszący te słowa miał natomiast przyjemność współpracować nad stroną organizacyjną i merytoryczną objazdu, a także wraz z dr Katarzyną Pyżewicz i dr Mileną Teską był opiekunem studentów biorących udział w podróży.

Po 27 latach od ostatniej podróży środowisko naukowe Instytutu Prahistorii zorganizowaną grupą powróciło na Półwysep Iberyjski. Objazd odbył się w dniach 3-10 marca 2013 r. i wzięło w nim udział 53 uczestników: oprócz studentów II roku, także kadra dydaktyczna 
Instytutu Prahistorii, studenci wszystkich lat studiów licencjackich i magisterskich, doktoranci oraz absolwenci poznańskiej archeologii. Podstawowym celem było zwiedzenie najważniejszych stanowisk archeologicznych położonych w północno-wschdniej części Półwyspu Iberyjskiego oraz reprezentatywnych dla archeologii śródziemnomorskiej kolekcji muzealnych. Poza miejscowościami odwiedzonymi w trakcie dwudniowej drogi na Półwysep Iberyjski, w samej Hiszpanii uczestnicy zwiedzili rzymskie zabytki w Barcelonie: świątynię Augusta, mury miejskie, pozostałości po akweduktach, nekropolę, a także Muzeum Archeologii Katalonii. Spośród odwiedzonych stanowisk archeologicznych najważniejsze były: osada iberyjska w Ullastret, kolonia grecka i miasto rzymskie w Ampurias, dolmen w Romanya de la Selva, akwedukt „Pont del Diable”, willa rzymska w Altafulla, a także oppidum w Ensérune. Uczestnicy objazdu zwiedzili również Muzeum Archeologiczne w Geronie oraz rzymskie i wczesnochrześcijańskie zabytki Tarragony, takie jak mury miejskie, amfiteatr, pozostałości forum wraz z Muzeum Archeologicznym. Na temat wszystkich zabytków studenci II roku sporządzili referaty omawiające historię, stan badań i znaczenie wybranych przez siebie obiektów. Po powrocie do Polski przygotowali również plakat przedstawiający pokonaną trasę i odwiedzone zabytki.

Objazd nie doszedłby do skutku, gdyby nie wsparcie władz Uniwersytetu: dofinansowanie Pana Prorektora ds. Studenckich, Pana Dziekana Wydziału Historycznego i Pani Dyrektor Instytutu Prahistorii obniżyło o ponad 1/3 koszty uczestnictwa studentów II roku w przedsięwzięciu. Dla osób, które z różnych powodów nie mogły pojechać do Hiszpanii, w dniach 17-18 kwietnia 2013 r. zorganizowany został objazd po zabytkach i muzeach Kujaw oraz Wielkopolski (Gołuchów, Kalisz, Giecz, Biskupin, Strzelno, Kruszwica, Gniezno, Ostrów Lednicki), z finansowym wsparciem Pani Dyrektor Instytutu Prahistorii oraz szczególnym zaangażowaniem dr Katarzyny Pyżewicz i dr. Artura Różańskiego, a także dr Mileny Teski, dr. Michała Pawlety i niżej podpisanego.

Michat Krueger

Instytut Prahistorii, Uniwersytet im. A. Mickiewicza

ul. Św. Marcin 78, 61-809 Poznań, Poland

\section{JUBILEUSZOWA MIECDZYNARODOWA ARCHEOLOGICZNA KONFERENCJA NAUKOWA WE LWOWIE (22-24 MAJA 2013 R., LWÓW, UKRAINA)}

Archeologia jako nauka ma długą tradycję na zachodniej Ukrainie, a Lwów jest największym po Kijowie ośrodkiem dydaktyczno-badawczym. Obok archeologii uniwersyteckiej działa tu Instytut Ukrainoznawstwa im. Iwana Krypjakevyča Narodowej Akademii Nauk Ukrainy. To on właśnie organizuje coroczne międzynarodowe konferencje „Archeologia Zachodu Ukrainy".

Niemal sto referatów zgłoszonych do programu konferencji, ponad 120 archeologów i historyków z Białorusi, Polski, Rosji, Słowacji i różnych regionów Ukrainy - tak zaprezen- 